\title{
A SURVEY ON INFORMATION SERVICES OF ENGINEERING COLLEGES IN TUMAKURU DISTRICT
}

\author{
MAHESHA NAIK \\ Librarian, A.P.S. Evening College, N.R. Colony, Bangalore, Karnataka, India
}

\begin{abstract}
A survey was undertaken to learn about the services of libraries at the Engineering Colleges in Tumakuru city. The data has been collected mainly through distributing well designed questionnaire to library clients to get their opinion on the services of their libraries. The responses show that respondents did not feel their library had an adequate number of books. The survey also shows that a majority of the libraries are lagging behind to have adequate number of relevant journals in their libraries. Project report collection was not good at the libraries. Most of the users in all of the colleges, with the exception of SIT, have faced a shortage of textbook copies in their libraries and clients were not satisfied with the service rendered by the staff. About $40 \%$ of the users were not happy with the present system of issuing books. Interest shown by the staff in assisting with book searches was also not satisfactory. Few libraries were not providing reprographic services, inter- library loan service and reservation facility to reserve the books. In addition, there is lack of adequate space for reference work and the library patrons also felt that the book rental period at the libraries was too short.
\end{abstract}

KEYWORDS: Information Services, Library, Engineering Colleges \& Tumakuru

Received: Jul 15, 2017; Accepted: Aug 07, 2017; Published: Aug 16, 2017; Paper Id: IJLSRAUG20177

\section{INTRODUCTION}

Ever since the dawn of 'Swaraj', India has been making notable progress in several directions, and we can be legitimately proud of these achievements. Even so, we must concede that, despite the recommendations of several committees and commissions, our educational system, from the primary to the University stages, has remained, by and large, listless and stagnant, unresponsive to the vital needs of the nation (GARG 1990). It is therefore, imperative that we consider diver aspects of educational reform in depth and with a sense of emergency, so that, certain concrete measures could be taken for re-fashioning the current educational pattern in conformity with the pressing requirements of our times.

Generally, the term 'Library' connotes a store house of information in the form of print on paper and reports etc. and newer media such as films, filmstrips, video and audio cassettes. Most often, it is viewed that the library as a place, where such information 'containers' are acquired and organized for the purpose of consultation, search, extraction and information dissemination. While the walls of the libraries have diminishing use of technologies like OPACs, CD-ROMs and online systems, libraries are still largely associated with buildings that house variety of information (Agarwal, 1989).

Libraries are the vibrating central support services of any institution, which is concerned with teaching, learning and research. It is more so, in the case of engineering and technological colleges. Libraries help the users to get the information they want (Shukla, 1989). For this purpose, the library staffs have developed a number of 
tools and techniques. The classified arrangement of books on the shelves helps the users to locate the books.

The library catalogue helps the users to know a book or information is available in the library. The various maps, guides etc. provided in the library helps the users to find their way in the complex library mechanism and the reference services provided by the library staff, whenever the user needs.

The first engineering college was started by the Mysore government in 1917 at Bengaluru. After 1946, three more colleges were started. By the time of integration of the state, there were totally five engineering colleges ( 2 governments $\&$ 3 private) in the state. By 1993-94, there were a total of 47 engineering colleges in the state, of which, 4 were government institutions, nine were aided and rest were unaided (Sridhar, 1990).

Tumakuru is located on the Bengaluru-Pune national highway No.4, and is about $65 \mathrm{~km}$ from the garden city, Silicon Valley of India and the capital of Karnataka 'Bengaluru'. Tumakuru is surrounded by picturesque hills like Siddaganga Hills, Devarayana Durga, Shivaganga and Goravanahalli Lakshmi Temple and so on.

There are 4 engineering colleges in Tumakuru city alone namely, Siddaganga Institute of Technology, Sri Siddartha Institute of technology, HMS Institute of technology and Shridevi Institute of technology. Apart from this, there are 2 colleges in Tumakuru district viz., Kalpataru Institute of technology in Tiptur and Sri Channabasaveshwara Institute of technology in Gubbi.

This study has narrated the various available services in the engineering colleges in Tumakuru city.

\section{METHODOLOGY}

The study was limited to the four Engineering College Libraries in Tumakuru city viz., HMS Institute of Technology (HMSIT), Shridevi Institute of Technology (SIET), Siddaganga Institute of Technology (SIT) and Sri Siddartha Institute of Technology (SSIT). The main objectives of the study were to know the services rendered by the libraries, to understand the user's needs, to know the utilization of the library service and to improve the quality of service.

The data for the study was collected through distributing a well designed questionnaire. Questionnaires were distributed randomly to all Engineering college library clients to get their opinion regarding the services of their libraries. The percentage of respondents was 100.The information extracted from them was considered as adequate and reliable. About 70 male and 30 female clients from HMSIT, SIET and SIT were covered and 40 male and 60 female clients were covered from SSIT libraries.

\section{RESULTS AND DISCUSSIONS}

Only in SIT college library, about $90 \%$ of the users agreed that library is having enough collection of books. In SIET and SSIT College libraries, $80 \%$ of the clients were satisfied with the library book collection and in HMSIT, $60 \%$ of the users were satisfied (Table 1). Twenty per cent each from SIET and SSIT and $40 \%$ from HMSIT, $10 \%$ from SIT were not satisfied with the library collection.

Journals/Periodicals are very important sources of information, especially for the higher education. It provides recent developments in their respective areas. The survey shows that majority of the libraries were lagging behind to have adequate number of relevant journals in their libraries. Two extreme views were expressed by SIT and HMSIT users. In SIT, all the students were favored, whereas in HMSIT all the students were not happy with the collection. In other two 
colleges, $30 \%$ of users were not satisfied (Table 1). All the respondents in HMSIT said 'NO' to the question. Overall $40 \%$ of respondents were not satisfied with the journal collection in their libraries. Overall, $52.5 \%$ of the users in all the colleges were not satisfied with the collection of reports in their libraries.

Table 1: Response of Clients towards the Collection of Books, Journals and Project Reports in Library

\begin{tabular}{|l|c|c|c|c|c|c|}
\hline \multirow{2}{*}{ Colleges } & \multicolumn{2}{|c|}{ Books } & \multicolumn{2}{c|}{ Journals } & \multicolumn{2}{c|}{ Project Reports } \\
\cline { 2 - 7 } & Satisfied (\%) & $\begin{array}{c}\text { Not Satisfied } \\
(\boldsymbol{\%})\end{array}$ & Satisfied (\%) & $\begin{array}{c}\text { Not Satisfied } \\
(\boldsymbol{\%})\end{array}$ & Satisfied (\%) & $\begin{array}{c}\text { Not Satisfied } \\
(\boldsymbol{\%})\end{array}$ \\
\hline HMSIT & 60 & 40 & - & 100 & 50 & 50 \\
\hline SIET & 80 & 20 & 70 & 30 & 30 & 70 \\
\hline SIT & 90 & 10 & 100 & - & 80 & 20 \\
\hline SSIT & 80 & 20 & 70 & 30 & 30 & 70 \\
\hline Total & $\mathbf{7 7 . 5}$ & $\mathbf{2 2 . 5}$ & $\mathbf{6 0}$ & $\mathbf{4 0}$ & $\mathbf{4 7 . 5}$ & $\mathbf{5 2 . 5}$ \\
\hline
\end{tabular}

Multiple copies of books must be there in the libraries for the betterment of engineering students. About $90 \%$ of the students from SIT were satisfied with the presence of multiple copies of books, whereas 50, 60 and $40 \%$ of students from HMSIT, SIET and SSIT were satisfied, respectively. Average of $60 \%$ of students from all the colleges were satisfied with the presence of multiple copies of books in their libraries and $40 \%$ were not satisfied (Table 2 ). About $40 \%$ of the respondents from SSIT were not satisfied with the service render by the library staff. But, majority of the respondents were satisfied (Table 2).

Table 2: Response of Users towards the Presence of Adequate Number of Multiple Copies of Text Books and Service Rendered by the Staff

\begin{tabular}{|l|c|c|c|c|c|c|}
\hline \multirow{2}{*}{ Colleges } & \multicolumn{2}{|c|}{ Multiple Copies of Books } & \multicolumn{4}{c|}{ Service by Library Staff } \\
\cline { 2 - 7 } & Satisfied (\%) & Not Satisfied (\%) & Very Satisfied & Satisfied & Not Satisfied & Can't Say \\
\hline HMSIT & 50 & 50 & - & 100 & - & - \\
\hline SIET & 60 & 40 & - & 100 & - & - \\
\hline SIT & 90 & 10 & - & 100 & - & - \\
\hline SSIT & 40 & 60 & - & 60 & 40 & - \\
\hline Total & $\mathbf{6 0}$ & $\mathbf{4 0}$ & - & $\mathbf{9 0}$ & $\mathbf{1 0}$ & - \\
\hline
\end{tabular}

Almost all the respondents from all the colleges were satisfied or free to access the books of their choice in open access system (Table 3). Time is very precious for everybody, especially research scholars, professors, higher education students etc. While issuing a book, staff should take less time. This will save the time of the reader. This is one of the important laws in library science. About $50 \%$ of the students from HMSIT, $90 \%$ from SIET, $60 \%$ from SIT and $40 \%$ of the students from SSIT were satisfied with the time taken to issue a book from library because, the staff took less than 5 minute to issue a book (Table 3). Average of $60 \%$ of students was satisfied and $40 \%$ of the respondents were not satisfied with the time taken to issue a book.

Table 3: System Preferred to Borrow Books and Time Taken to Borrow Book from Library

\begin{tabular}{|l|c|c|c|c|}
\hline \multirow{2}{*}{ Colleges } & \multicolumn{2}{|c|}{ System of Preference } & \multicolumn{2}{c|}{ Time Taken to Borrow Book } \\
\cline { 2 - 5 } & Open Access & Closed Access & Less than 5 min. & More than 5 Min. \\
\hline HMSIT & 100 & - & 50 & 50 \\
\hline SIET & 100 & - & 90 & 10 \\
\hline SIT & 100 & - & 60 & 40 \\
\hline SSIT & 100 & - & 40 & 60 \\
\hline \multicolumn{1}{|c|}{ Total } & $\mathbf{1 0 0}$ & - & $\mathbf{6 0}$ & $\mathbf{4 0}$ \\
\hline
\end{tabular}


The motto of library staff is to provide the right information to its clients at right time. In HMSIT, only $10 \%$ of the clients were very much satisfied, $30 \%$ from SIET, $20 \%$ from SIT library clients were very much satisfied with the interest shown by the library staff. An average of $15 \%$ of the respondents and $70 \%$ of respondent's response was very much satisfied and satisfied respectively. Overall, $7.5 \%$ of the students were not satisfied with the response provided by the staff. Another $7.5 \%$ of students were not able to answer for the question (Table 4).

Table 4: Interest Shows by the Staff in Search of Books

\begin{tabular}{|l|c|c|c|c|}
\hline \multirow{2}{*}{ Colleges } & \multicolumn{4}{|c|}{ Staff Response (\%) } \\
\cline { 2 - 5 } & Very Much Satisfied & Satisfied & Not Satisfied & Can't Say \\
\hline HMSIT & 10 & 90 & - & - \\
\hline SIET & 30 & 60 & - & 10 \\
\hline SIT & 20 & 50 & 20 & 10 \\
\hline SSIT & - & 80 & 10 & 10 \\
\hline \multicolumn{1}{|c|}{ Total } & $\mathbf{1 5}$ & $\mathbf{7 0}$ & $\mathbf{7 . 5}$ & $\mathbf{7 . 5}$ \\
\hline
\end{tabular}

Reference section is very important section in the library. This section should be separate from the issue section with enough space for sitting with enough space for sitting. Out of four engineering colleges in Tumakuru, two college students viz., SIT and SSIT gave full marks to their libraries. But, HMSIT and SIET students were not satisfied with the arrangement of reference section in their college library (Table 5). Reprographic services must be provided in the libraries for taking Photostat copies of the documents. Only two colleges viz., SIT and SSIT have this facility and other two colleges do not have this service (Table 5). Out of four engineering colleges, only one college SSIT provides internet services to its students. Other two colleges do not have this facility (Table 5). Inter- library loan facility refers to the request for the document, which is not available in the library. Whatever might be the nature of a library, but it should take advantage of borrowing books from other libraries, especially those in the same town itself. About $50 \%$ students of SIET college knew about the inter library loan facility. Other colleges do not have this facility (Table 5). In case, document has been loaned and a user needs it, he can get this by reserving the document. In SIET College, $80 \%$ of respondents said that the library does not have this service. Overall, 27.55 respondents in all the colleges said NO to the question (Table 5).

Table 5: Response of Users for the Space Provided for Reference Work in Library, Reprographic Service, Internet Facility, Inter-Library Transfer of Books and Reservation Facility

\begin{tabular}{|l|c|c|c|c|c|c|c|c|c|c|}
\hline Colleges & $\begin{array}{c}\text { Adequate Space } \\
\text { in Library for } \\
\text { Reference Work }\end{array}$ & $\begin{array}{c}\text { Reprographic } \\
\text { Service } \\
\text { Available }\end{array}$ & \multicolumn{2}{|c|}{$\begin{array}{c}\text { Internet } \\
\text { Facility }\end{array}$} & \multicolumn{2}{|c|}{$\begin{array}{c}\text { Inter-Library } \\
\text { Facility }\end{array}$} & \multicolumn{2}{c|}{$\begin{array}{c}\text { Reservation } \\
\text { Facility }\end{array}$} \\
\hline & Yes & No & Yes & No & Yes & No & Yes & No & Yes & No \\
\hline HMSIT & 40 & 60 & - & 100 & - & 100 & - & 100 & 100 & - \\
\hline SIET & 50 & 50 & - & 100 & - & 100 & 50 & 50 & 20 & 80 \\
\hline SIT & 100 & - & 100 & - & - & 100 & - & 100 & 80 & 20 \\
\hline SSIT & 100 & - & 100 & - & 100 & - & - & 100 & 90 & 10 \\
\hline Total & $\mathbf{7 2 . 5}$ & $\mathbf{2 7 . 5}$ & $\mathbf{5 0}$ & $\mathbf{5 0}$ & $\mathbf{2 5}$ & $\mathbf{7 5}$ & $\mathbf{1 2 . 5}$ & $\mathbf{8 7 . 5}$ & $\mathbf{7 2 . 5}$ & $\mathbf{2 7 . 5}$ \\
\hline
\end{tabular}

About $80 \%$ of the respondents were satisfied with the time given by the libraries to hold the books, $15 \%$ of the students were not satisfied with this and $5 \%$ of the students were not aware of this. There was $100 \%$ in favor of the SIT college library with the library timings and about $20 \%$ of responses from other colleges need their library timings to be extended (Table 6). 
Table 6: Response of Users for the Duration of Returning Books and for the Library Timings

\begin{tabular}{|l|c|c|c|c|c|c|}
\hline \multirow{2}{*}{ Colleges } & \multicolumn{3}{|c|}{ Duration of returning books } & \multicolumn{2}{c|}{ Library timings } \\
\cline { 2 - 7 } & Very Much Satisfied & Satisfied & Not Satisfied & Can't say & Satisfied (\%) & Not Satisfied (\%) \\
\hline HMSIT & 10 & 60 & 20 & 10 & 80 & 20 \\
\hline SIET & 40 & 50 & 10 & - & 80 & 20 \\
\hline SIT & 50 & 40 & 10 & - & 100 & - \\
\hline SSIT & - & 70 & 20 & 10 & 80 & 20 \\
\hline Total & $\mathbf{2 5}$ & $\mathbf{5 5}$ & $\mathbf{1 5}$ & $\mathbf{5}$ & $\mathbf{8 5}$ & $\mathbf{1 5}$ \\
\hline
\end{tabular}

\section{CONCLUSIONS}

This survey was undertaken to learn about the services of the libraries at the Engineering Colleges in Tumakuru city. A well-designed questionnaire was administered to library clients to get their opinion on the services of their libraries. The responses show that respondents did not feel their library had an adequate number of books. The survey also shows that a majority of the libraries are lagging behind in having an adequate number of relevant journals available in their libraries. The survey also reports that collection is not good at the libraries. Most of the users in all of the colleges, with the exception of SIT, have faced a shortage of textbook copies in their libraries. Service given by the staff was not satisfactory. About $40 \%$ of the users are not happy with the present system of issuing books. Interest shown by the staff in assisting with book searches was also not satisfactory. There is lack of adequate space in the libraries for reference work. Photocopying services were not provided in few of the libraries. There is no inter-library loan service provided. There was no system for reserving books at some libraries. Library patrons also felt that the book rental period at the libraries was too short.

\section{REFERENCES}

1. Agrawal, S. P. (1989). Development of library services in India, Concept Publishing Company, New Delhi.

2. Garg, V.P., (1990). Development perspective of Indian education, Metropolitan, New Delhi.

3. Shukla, B.B., (1989). Library Extension Services, Bharathi, Cuttack

4. Sridhar, M. S., (1990). User Education, Biblio Infon Service, Bangalore. 
